\title{
SURVEY ON THE EFFECTIVENESS OF ONLINE LECTURES DURING COVID-19 PANDEMIC: METHODS AND DIFFICULTIES
}

\author{
${ }^{1}$ Aristo Hardinata, ${ }^{1}$ Halim Simatupang, ${ }^{2}$ Fatin Hanifa, ${ }^{3}$ Abdul Latip, ${ }^{4}$ Shelly Efwinda, \\ and ${ }^{5}$ Relsas Yogica. \\ ${ }^{1}$ Department of Science Education, Universitas Negeri Medan \\ ${ }^{2}$ Department of Psychology, Universitas Abdurrab \\ ${ }^{3}$ Department of Science Education, Universitas Garut \\ ${ }^{4}$ Department of Physic Education, Universitas Mulawarman \\ ${ }^{5}$ Department of Biology, Universitas Negeri Padang \\ aristohardinata@unimed.ac.id
}

Accepted: December $6^{\text {th }}, 2020$. Published: December $31^{\text {th }}, 2020$

\begin{abstract}
This study aims to describe the effectiveness and method of lectures that took place during the Covid-19 pandemic. The Covid-19 pandemic requires all aspects of life to adapt, including in the field of education. This research is a descriptive quantitative study with a simple survey method using an instrument in the form of a google form which was designed to find out what students and lecturers think about lectures during the Covid-19 pandemic. The opinion in question was an opinion about the method or media used as well as the difficulties faced in the implementation of online lectures during the pandemic. This study used a purposive sampling technique, namely 5 universities in Indonesia consisting of 200 lecturers and 200 students. All respondents were asked to fill out an online questionnaire in the form of a google form designed to find out the methods or media used in lectures as well as the difficulties faced in using the media. The survey results show that the combination of media that was mostly used by lecturers and students in lectures is Whatsapp Group, Zoom Meeting, campus E-Learning Website, and Google Classroom. The majority of difficulties experienced by lecturers and students in online implementation are the uneven quality of internet connections. Lecturers find it difficult to psychologically assess students who are attending lectures. Lecturers cannot ensure the seriousness of students in the lecture process. In addition, the lecturer also feels that it takes a lot of time in the matter of using the application or media technically, so it is quite disruptive to the course of lectures such as the slow pace of learning media and the length of time required for students to join in the meeting. Lecturers and students still consider online lectures to be ineffective.
\end{abstract}

Keywords: Survei, Effectiveness, Learning, Pandemi Covid-19, Student and Lecturer Responses 


\section{Introduction}

Currently, the entire population of the world in general and Indonesia in particular are facing a complicated outbreak of a virus that is not yet known when the end of the resolution is. This virus outbreak is known as the corona virus. This corona virus was first discovered in 1965 when scientists DA Tyrrell and ML Bynoe from Harvard Hospital, England carried out isolation of viruses obtained from human breathing who experienced flu symptoms. Then the next researchers found a similar virus that can be found in humans as well as animals. These viruses are named the corona virus because of their crown shape. This corona virus can cause acute respiratory infections in humans, requiring intensive care and even death. Unlike the previous corona virus outbreak, the latest outbreak that is currently being faced by the world community is called the Covid-19 virus. This outbreak began to appear at the end of 2019 which was originally discovered in Wuhan, Hubei Province, China. The covid-19 virus is said to have originated from bats which then spread to other animals to humans. Unlike the previous coronavirus, this virus that was thought to have evolved has a higher transmission rate. The covid-19 virus is also a dangerous virus because there are no symptoms 2 to 14 days after infection. Until finally humans who are infected with this virus will experience respiratory problems, kidney failure and death. This virus can be transmitted easily through liquid splashes such as from sneezing, coughing, and even touching the skin so that prevention requires us to keep our distance, which we often hear today as social distancing. Until now, no effective treatment has been found against the Covid-19 virus. In addition, to handle it, it requires large funds and special facilities so that it is quite overwhelming for the government. Therefore, all citizens of the world through their respective governments have moved to implement social distancing to prevent the spread of the Covid-19 virus. In Indonesia in particular, the government has implemented Large-Scale Social Restrictions in almost all parts of Indonesia, and there are even some areas that have carried out regional isolation or known as lockdown. But in fact, until now, the victims caused by the Covid-19 virus have not shown any indication of a decline. In China itself, as a country that was the beginning of the emergence of the Covid-19 virus, at first it had succeeded in breaking the network of this spread, but again the same cases were found.

From the website of the world health organization (WHO) as the world's largest organization in the health sector, which intensively monitors the development of the Covid-19 virus outbreak, reports that cases have reached 4,258,666, with 294,190 cases that have caused death in 216 countries including Indonesia as of the 14th May 2020. Meanwhile, from the website data of the Task Force for the Acceleration of Handling Covid-19 in Indonesia, data were obtained from 16,006 confirmed cases with 1,043 deaths (6.5\%) of those confirmed. Even based on news summarized from Kompas.com, that the peak of the Covid-19 cases occurred on Wednesday, May 13, 2020, with 689 confirmed cases within a day. This is of course a deep concern for the entire world population, especially Indonesia.

The problem that has arisen since the implementation of social distancing and Large-Scale Social Restrictions by the government in order to prevent the spread of the Covid-19 virus, it can be said that people all over the world stop and cannot carry out their usual activities. All sectors of life such as the economy are very shaken as well as the education sector. Since March 2020, all university campuses, high schools, and elementary schools have implemented online education or distance education. Based on a circular from the Ministry of Education and Culture (Kemendikbud) number 36962 / MPK.A / HK / 2020, all employees, teachers, and lecturers are required to work, teach, or give lectures from home through video conferencing, digital documents, and other online tools.

\section{Research Method}

This research method was a descriptive quantitative method that aims to describe the research results from simple calculated numbers (Sugiyono, 2017). The 
data collection technique used was a simple survey technique using online services provided by the google company, namely google form, and then the quantitative data obtained was analyzed and described. This was carried out considering that it was still difficult to hold meetings or gather large numbers of people which could lead to the greater spread of the covid-19 virus.

The online questionnaire that was distributed in the form of google form contains components designed to determine the method or media used and the difficulties faced by lecturers and students in online lectures. The questions contained in the google form are (1) to (8) Do you use the following application as a medium or method used in the implementation of online lectures (Whatsapp Group, Zoom Meeting, Campus E-Learning Website, Cisco Webex, Google Classroom , Microsoft Team, Wikispaces, and others); (9) The time you need to prepare online lectures in one meeting; (10) The amount of quota or internet package that you spend each week; (11) Applications or media used in conducting online evaluations or examinations; (12) Difficulties and obstacles found in the implementation of online lectures; (13) Whether the online lecture you have conducted has been effective or not, give your reasons.

\section{Result and Discussion}

Result

This research was conducted at five university in indonesia with online survey. The sample used in this study were 200 lectures and 200 students from five university in Indonesia.

\section{Media or method used}

In this survey research, several methods or media used in lectures were asked of respondents. Some of these methods or media include Whatsapp Group (WAG), Zoom Meeting (ZM), Website eLearning (WeL), Cisco Webex (CW), Google Classroom (GC), Microsoft Team (MT), and Wikispaces (Ws).

Table 1. Online Media Combinations used in lectures.

\begin{tabular}{llc}
\hline No. & \multicolumn{1}{c}{ Kombinasi Metode } & $\begin{array}{c}\text { Persen } \\
(\boldsymbol{\%})\end{array}$ \\
\hline $\mathbf{1}$ & WAG, ZM, WeL, CW, GC, MT, Ws. & $\mathbf{0}$ \\
\hline $\mathbf{2}$ & WAG, ZM, WeL, CW, GC, MT. & $\mathbf{0}$ \\
\hline 3 & WAG, ZM, WeL, CW, GC & $\mathbf{0 . 3 3}$ \\
\hline 4 & WAG, ZM, WeL, CW, Ws. & $\mathbf{0 . 6 7}$ \\
\hline 5 & WAG, ZM, WeL, CW. & $\mathbf{0 . 6 7}$ \\
\hline 6 & WAG, ZM, WeL, GC. & $\mathbf{2 9 . 3 3}$ \\
\hline 7 & WAG, ZM, GC, MT. & $\mathbf{0 . 6 7}$ \\
\hline 8 & WAG, WeL, CW, GC. & $\mathbf{3 . 3 3}$ \\
\hline 9 & WAG, ZM, WeL. & $\mathbf{1 0}$ \\
\hline 10 & WAG, ZM, GC. & $\mathbf{2 4 . 6 7}$ \\
\hline 11 & WAG, ZM, MT. & $\mathbf{1 . 3 3}$ \\
\hline 12 & WAG, WeL, GC. & $\mathbf{6 . 6 7}$ \\
\hline 13 & ZM, WeL, GC. & $\mathbf{1 . 6 7}$ \\
\hline 14 & WAG, ZM. & $\mathbf{3 . 3 3}$ \\
\hline 15 & WAG, WeL. & $\mathbf{4 . 3 3}$ \\
\hline 16 & WAG, GC. & $\mathbf{8 . 0 0}$ \\
\hline 17 & ZM, WeL. & $\mathbf{2 . 3 3}$ \\
\hline 18 & ZM, GC. & $\mathbf{2 . 6 7}$ \\
\hline & & $\mathbf{1 0 0 \%}$ \\
\hline
\end{tabular}

Based on the data in the table, it was known that the 4 media combinations most often used by lecturers in the lecture process were using Whatsapp Group, Zoom Meeting, e-Learning Website, and Google Classroom, which amounted to $29.33 \%$, totaling 88 lecturers, Whatsapp Group, Zoom. Meeting, and Google Classroom by $24.67 \%$, amounting to 74 people, Whatsapp Group, Zoom Meeting, e-Learning Website by $10 \%$ for 30 people, Whatsapp Group and Google Classroom by $8 \%$, amounting to 24 people. In addition to the combination above, there are also several lecturers who use media or lecture methods, namely using schoology, edmodo, e-mail, and utilizing learning videos that are already available on the internet.

Average time and internet quota needed to prepare for online lectures

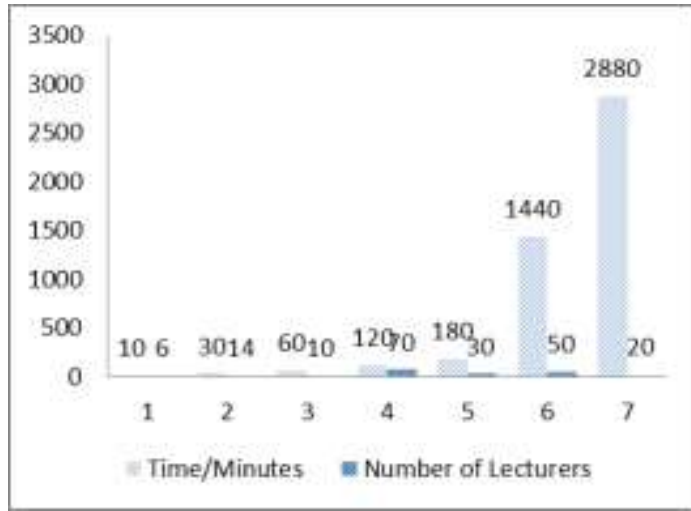


Graph 1. Average time in preparing online lecture materials by lecturers.

Based on the data in the graph, it can be seen that the time it takes for lecturers to prepare online learning there are various kinds of opinions. The highest number of respondents who answered was for 120 minutes with 70 respondents, while the smallest number of responses was 10 minutes with 6 respondents.

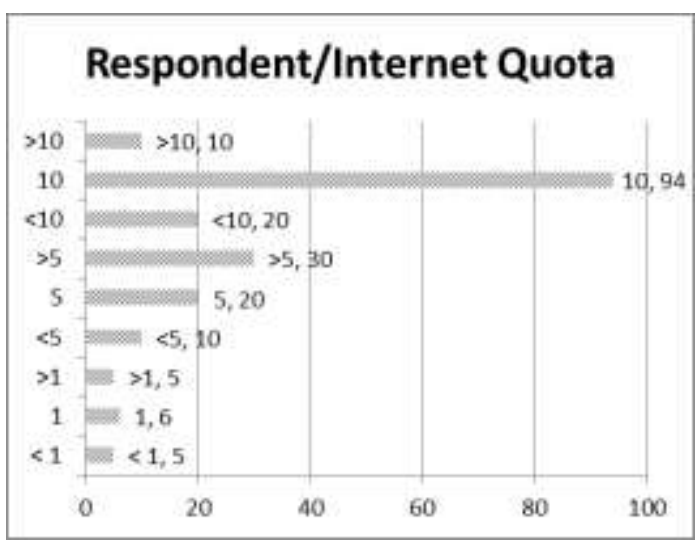

Graph 2. Average internet quota used

Based on the graph above, it can be seen that the internet quota used by lecturers and students who have the most response is 10 Gigabytes in one week. After that followed by a large of 5 gigabytes (> 5) with 30 respondents. The least response was 5 respondents at less than 1 gigabyte and greater than 1 gigabyte $(<1$ and $>1)$.

\section{Media used in online evaluations or exams}

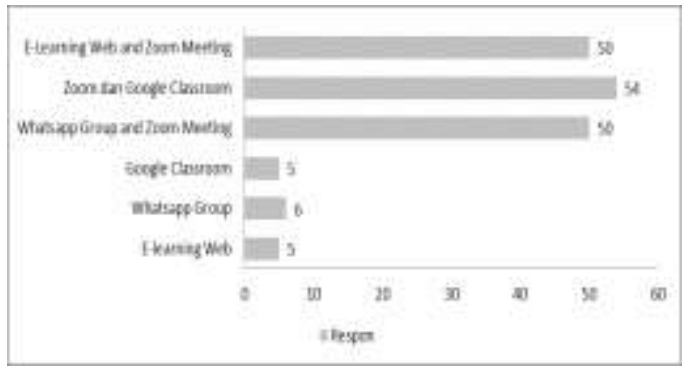

Graph 3. The media used in online evaluations or exams

Based on the graph above, it can be seen that the most respondents, namely 50 people, stated that they used a combination of google classroom, zoom meeting, whatsapp group, and e-learning website in conducting online exams.

Opinions of lecturers and students about the effectiveness of online lectures

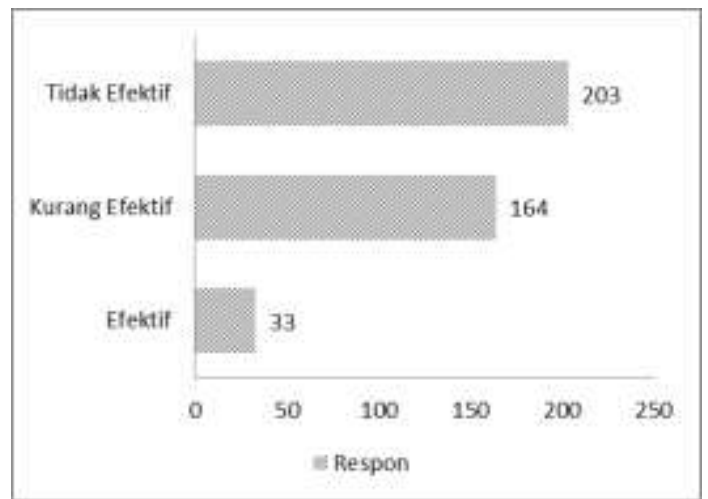

Graph 4. Lecturer and student responses to the effectiveness of online lectures.

Based on the data in the graph above, it can be seen that the average response from lecturers and students about the effectiveness of online lectures is less effective and ineffective, then only 33 responses from 400 respondents felt effective in the online lecture process. The various reasons given by the respondents will be explained in the discussion section.

\section{Discussion}

This study aims to find a simple picture of how online lectures will take place during the Covid-19 pandemic. Based on the data from graph 1, it can be seen that the most combinations carried out by lecturers in the implementation of online lectures are using the WhatsApp group, google classroom, zoom meeting, and e-learning websites provided by each respondent's campus. Based on these data it can be concluded that in fact WhatsApp is a social media that is very much in demand today and is widely used by all groups. This is in line with the results of research from Raharti (2019) who found that there was an increase in whatsapp users in the PUSPITEK work environment, namely 700 services $(63.35 \%)$. Raharti also explained that users prefer to use whatsapp services as a communication medium because they are simple in use. Another fact found in this study, based on a questionnaire given to lecturers, is the large 
number of e-learning websites used in lectures because several campuses in Indonesia require their lecturers to use elearning websites provided by campuses, for example SIPDA-Unimed ( Online Learning System-Medan State University). While the large use of google classroom services was caused at the beginning of the pandemic period, the services provided by the campus (e-learning website) were still often problematic, causing some lecturers to switch to preparing for their lectures using google classroom.

In this study it was also found that the average amount of internet quota used by lecturers and students in online lectures with the most response was 10 gigabytes in one week. It can be concluded that this is not a problem because according to the amount of assistance provided by the Indonesian government for the category of lecturers and students, which is 50 GB / month (Kemendikbud.go.id).

Based on Figure 3, the use of media in conducting online exams, many lecturers responded that online implementation was carried out using a combination of video conferencing applications, communication media, and e-leraning websites. Respondents gave the reason that by combining some of these media, especially video conferencing applications, lecturers could at least supervise online during the exam, rather than being left alone and giving students the opportunity to cheat.

Online lectures during the Covid-19 pandemic are a must to prevent and break the chain of spreading the Covid-19 virus. However, changing a habit is not as easy as turning the palm of the hand, in this case education or learning that was previously carried out almost fulltime face-to-face must be carried out fulltime online. This is of course quite difficult for both lecturers and students. Based on the data in graph 4, lecturers and students gave an average response stating that online lectures were considered ineffective and even ineffective. Lecturer respondents stated that it was quite difficult to deliver lecture material, especially lectures that required hands-on practical activities. Likewise, many students complain that there are too many assignments given. This is in line with the results of research from Gultom R.C. (2020) which states that $100 \%$ of students choose to study face-to-face. Likewise with the results of research from Wijayanengtias (2020) which found that students thought that online lectures were good for breaking the chain of covid-19 spread, but felt less satisfied in the implementation of online lectures because the available facilities were inadequate. However, many lecturer respondents also stated that with the current pandemic conditions, the combinations of media or methods they had compiled were quite effective.

Apart from the need for adequate facilities, it also requires good technological literacy skills for lecturers and students. Abdul Latip (2020) states that technological literacy is needed in the practice of distance learning so that distance learning can run smoothly, effectively, and provides opportunities for teachers and learners to collaborate well.

\section{Conclusion}

Based on the results and data analysis of this study, it can be concluded that:

1. In online lectures, the lecturer chooses to combine several available media and services so that lectures are more meaningful, such as whatsapp groups, zoom meetings, google classrooms, and campus e-learning websites.

2. It takes a long time and a large internet quota to carry out online lectures.

3. Lecturers and students still think that online lectures are not as effective as face-to-face lectures due to facilities and abilities in technological literacy.

Based on the results and conclusions of this study, there are several suggestions that can be given such as the implementation of research can be carried out more specifically in order to see the effectiveness or meaning of the learning process or lectures in more detail. It is hoped that this research can provide information for further researchers to produce lecture methods or designs that can lead to meaningful online lectures. 


\section{Reference}

Gultom. (2020). Persepsi Mahasiswa Unika Terhadap Kuliah Online di Masa Pandemi Covid-19. Pendidikan Bahasa Indonesia dan Sastra. Vol 3 No. $1 . \quad$ DOI: http://dx.doi.org/10.1234/pbis.v31.7 7

Kemendikbud.go.id. (2020). Buku Saku Program Kuota Belajar Bagi Siswa, Guru, dan Dosen. https://kuotabelajar.kemdikbud.go.id/Buku Saku (accessed on 9 November 2020).

Latip. A. (2020). Peran Literasi Teknologi Informasi Dan Komunikasi Pada Pembelajaran Jarak Jauh di Masa Pandemi Covid-19. Jurnal Edukasi dan Teknologi Pembelajaran, Vol. 1, No.2. 107-115.

Rahartri. (2019). "Whatsapp" Media Komunikasi Efektif Masa Kini (Studi Kasus Pada Layanan Jasa Informasi Ilmiah Kawasan PUSPIPTEK). Visi Pustaka, 2, Vol. 21, 147-156.

Sugiyono. (2017). Metode Penelitian Kuantitatif, Kualitatif dan R \& D. Bandung: Alfabeta.

Wijayanengtias. (2020). Student Perceptions of Online Learning During the Covid-19 Pandemic. Vol 9 No. 1. 16-21. 